\title{
Status of Coastal Plantation in Chittagong Coastal Forest Division
}

\author{
Rimana Islam Papry \\ Institute of Forestry and Environmental Sciences, University of Chittagong, Chittagong-4331, Bangladesh
}

\begin{abstract}
The study was conducted to highlight the status and beneficial role of coastal plantation in Chittagong Coastal Forest Division. Mangrove, non-mangrove and strip plantation were raised in 70 beats under12 ranges in the Division. Among all the Ranges, mangroves were dominant and cover an area of 46367.94 ha plantations. Coastal plantations damages during natural calamities but mostly damages by manmade activities which makes coastal areas more vulnerable to natural disasters. Mangroves and coastal forests play an important role to reduce the damages and protect human lives by acting as protective shield during extreme natural events. Coastal plantation provides benefits in terms of disaster mitigation, protection of lives and resources, living standard and resource development and preservation of environment.

Key words: Chittagong Coastal Forest Division, Coastal Plantation, Mangrove, non-mangrove and strip plantation, Ranges, Beneficial role of coastal plantation.
\end{abstract}

\section{Introduction}

The term coast is used to indicate the zone of contact between land and the sea (Bhuiyan and Anam, 2006). It is an intermediate zone that extends land ward from the shore. A coast may be a gently sloping plain; it may terminate abruptly in a stiff cliff or it may be characterized by other types of topography (Bandyopadhay, 1997). Bangladesh is a developing country of low deltaic plain located between $20^{\circ} 34^{\prime \prime}$ to $26^{\circ} 38^{\prime \prime}$ North latitude and $88^{\circ} 01^{\prime \prime}$ to $92^{\circ} 41^{\prime \prime}$ East longitude (Rashid, 1991). The whole coast runs parallel to the Bay of Bengal, forming $710 \mathrm{~km}$ long coastline from mouth of the Teknaf River in the southeast to the mouth of the Raimangal River in the west (CZPo, 2005). The coastal zone covers $47,201 \mathrm{~km}^{2}$ land area, which is $32 \%$ of total landmass of the country (Islam, 2004).

The coastal afforestation program was started in 1965-66 and the Government of Bangladesh has a unique afforestation program on the newly forming lands of the Bay of Bengal. The government has decided that all new accretions in the Bay will be afforested to ensure their stabilizations and to ensure further accretions (Rachid, 1977).

Now the coastal plantations established in the coastal areas are administered by four Coastal Afforestation Divisions namely, from east to west, Chittagong, Noakhali, Barisal and Patuakhali and subdividing into 28 forest Ranges and 198 beats (Drigo et al., 1987). Till 2010, an area of 170,000 ha coastal area has been planted, although there are plantation failures over a considerable area (Aziz, 2010).

During the last four decades, the Forest Department has successfully implemented massive plantation programmes and has established some 172,000 ha of mangrove plantation scattered over coastal areas and offshore islands of the country (Hossain et al., 2008). In addition to these, the other mangrove plant were also tried to raise in borrow pits. Species planted in borrow pits showed reasonably good success (Choudhury, 1982). Species tried were Keora (Sonneratia apetala), Baen (Avicennia officinalis), Kankra (Bruguira gymnorhiza), Golpata (Nypa fruticans) and Gewa (Excoecaria agallocha) (Choudhury, 1982). Newly accreted lands grow and colonize first, trap sediments and bind deposited sediments more effectively (Siddiqi, 2001). The first colonizer comes naturally is Urigrass (Karim, 1994), then after some years mangrove bushes appears. Depending on the soil condition then appear Keora, Baen, Kankra etc. on the land, and finally a dynamic mangrove ecosystem is established (Choudhuri and Choudhury, 1994).

The present coastal afforestation works involved correct assessment of the locality factor, site quality and the selection of species for different site classes and ultimately to plant up the areas with the suitable species (Choudhury, 1982).

Chittagong Coastal Forest Division plays an important role in forest management of Bangladesh. Area of the Chittagong Coastal Forest Division is 86314.02 hectares which lies in Chittagong and Cox's Bazar administrative districts. (Source: DFO office, Chittagong Division).

Every year various natural disasters makes life very difficult which includes flood, cyclone, storm surge, tornado, earthquake, sea-level rise, coastal erosion and landslides and causes serious damages and massive loss to life and properties (Al-Hossaini et al., 2005).Shoreline forests are recognized as a buffer against the actions of wind, waves and water under tidal influence as a protection measure (Lyche, 1991). Therefore, the present study 
was undertaken for assessing the status and importance of Coastal Afforestation with their beneficial role under the Chittagong Coastal Forest Division.

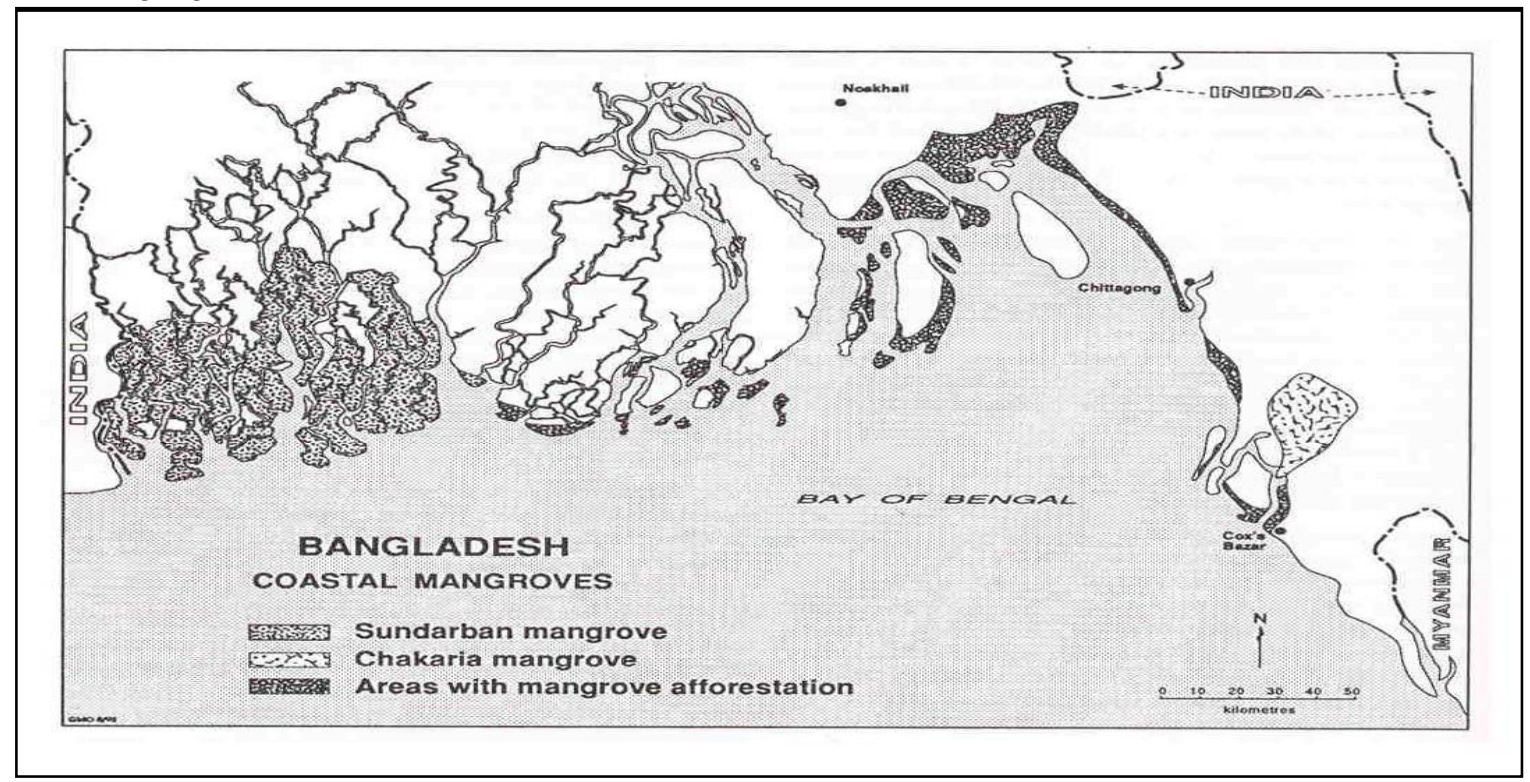

Figure 1: Map of Bangladesh coast showing the location of coastal forests

Projects/ schemes for coastal plantation

Table1: Projects/ schemes for coastal forests executed by the Forest Department, Bangladesh. (Source-Islam, 2007)

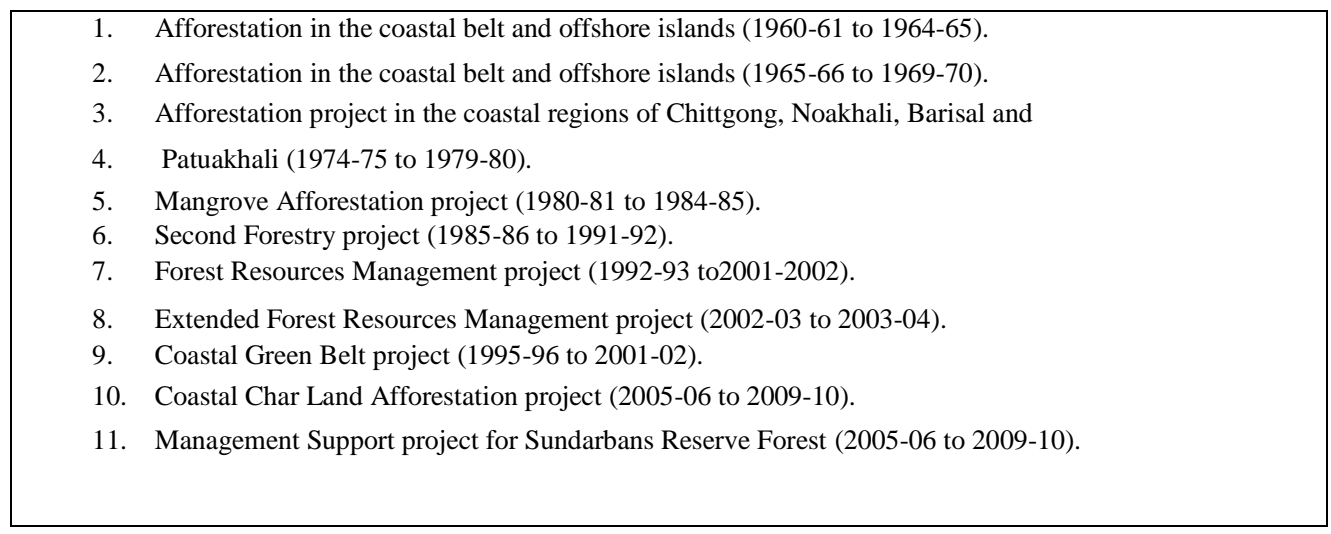

\section{Materials and methods}

Several ranges and beats were selected randomly for the study and visited several times to have an overall idea of the plantation. The study carried out by collecting information from range officers and local people about types and quantity of plantation. The information and relevant literature, which were required for conducting this study, were collected from different books, journals, published paper, previous paper, news paper, articles, scientific magazines and most importantly from Chittagong coastal forest division.

III. Result and discussion

Table-2:Name of Ranges under the Chittagong Coastal Forest Division

\begin{tabular}{|r|l|}
\hline Sl no. & Name of Ranges \\
\hline 1. & Gorokghata \\
\hline 2. & Sondwip \\
\hline 3. & Kutubdia \\
\hline 4. & Sitakundu \\
\hline 5. & Chanua \\
\hline 6. & Banshkhali \\
\hline 7. & Sadar \\
\hline 8. & Miraswarai \\
\hline 9. & Teknaf \\
\hline 10. & Urichor \\
\hline
\end{tabular}




\begin{tabular}{|r|l|}
\hline 11. & Moheshkhali \\
\hline 12. & Charandwip \\
\hline
\end{tabular}

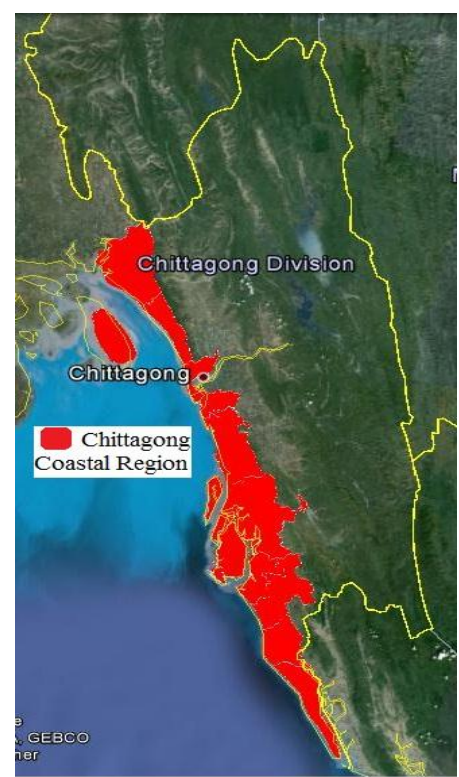

Figure2: Chittagong coastal region (Source: Chittagong Coastal Forest Division)

\section{Range wise Coastal Plantation:}

There are 12 Forest Ranges under the Chittagong Coastal Forest Division. Different types of plantations were raised in these ranges according to their site suitability. Mangrove plantations are the dominant in all the ranges. Large areas of mangrove plantation were raised in Urichor Range. Among all the ranges, large areas of non mangrove plantation were raised in Moheshkhali and lowest in Charandwip. In case of strip plantation, highest plantation was in Sadar range (Table: 3 )

Table 3: Coastal plantation under Chittagong Coastal Forest Division.

\begin{tabular}{|c|c|c|c|c|c|c|c|}
\hline SI No. & Range & Mangrove (ha) & $\%$ & $\begin{array}{c}\text { Non mangrove } \\
(\mathbf{k m})\end{array}$ & $\%$ & $\begin{array}{c}\text { Strip } \\
\text { plantation } \\
(\mathbf{k m})\end{array}$ & $\%$ \\
\hline 1. & Gorokghata & 8129.9 & 18 & 232.66 & 6 & 25 & 2 \\
\hline 2. & Sowndwip & 2891.06 & 6 & 132.26 & 3 & 116 & 10 \\
\hline 3. & Kutubdia & 867.98 & 2 & 93.26 & 2 & 28 & 2 \\
\hline 4. & Sitakundu & 3014.24 & 7 & 183.09 & 5 & 153.5 & 13 \\
\hline 5. & Chonua & 1303.84 & 3 & 45.96 & 1 & 64 & 5 \\
\hline 6. & Bashkhali & 3345.64 & 7 & 143.49 & 4 & 158.2 & 14 \\
\hline 7. & Sadar & 4373.98 & 9 & 236.43 & 6 & 267.25 & 23 \\
\hline 8. & Miroswarai & 6481.02 & 14 & 134 & 3 & 173 & 15 \\
\hline 9. & Teknaf & 2179.04 & 5 & 115 & 3 & 85 & 7 \\
\hline 10. & Urichor & 12125.41 & 26 & 90 & 2 & - & 0 \\
\hline 11. & Moheshkhali & 534.54 & 1 & 2667.3 & 65 & 9 & 1 \\
\hline \multirow[t]{2}{*}{12.} & Charandwip & 1121.29 & 2 & - & 0 & 93 & 8 \\
\hline & Total & 46367.94 & 100 & 4073.43 & 100 & 1171.95 & 100 \\
\hline
\end{tabular}

Source: Chittagong Coastal Forest Division

\section{Transfer of degraded forest land}

Chittagong Coastal Forest Division has contributed 22,176.28 acres for practicing participatory forestry by transferring coastal forest lands to the district administration (Table:4)

\begin{tabular}{|c|c|}
\hline District & Notified land (acre) \\
\hline Chittagong & $9,834.47$ \\
\hline Cox'sbazar & $12,341.81$ \\
\hline Total & $22,176.28$ \\
\hline
\end{tabular}


Nature and Area of Reserve Forests under Chittagong Coastal Forest Division

Total area of the hill and Mangrove forest were 86314.02 ha, area under plantation were 42500.62 ha and area under encroachment were 9464.09 ha and natural forest/barren land were 34349.30 ha (Table: 5) and (Fig: 3)

Table 5: Nature and Area of Reserve Forests

\begin{tabular}{|c|c|c|c|c|c|}
\hline Nature & Status & Total area (ha) & $\begin{array}{c}\text { Area under } \\
\text { plantation (ha) }\end{array}$ & $\begin{array}{c}\text { Area under } \\
\text { encroachment (ha) }\end{array}$ & $\begin{array}{c}\text { Natural } \\
\text { forest/Barren (ha) }\end{array}$ \\
\hline Hill Forest & Reserved Forest & 7400.25 & 2559.91 & 1370.37 & 3469.96 \\
\hline \multirow{2}{*}{ Mangrove Forest } & $\begin{array}{c}\text { Notified under } \\
\text { section 4 and 6 of } \\
\text { Forest Act of 1927 }\end{array}$ & 78913.77 & 39940.71 & 8093.72 \\
\hline & Total & 86314.02 & 42500.62 & 9464.09 & 30879.34 \\
\hline
\end{tabular}

Source: DFO Office, Chittagong Division

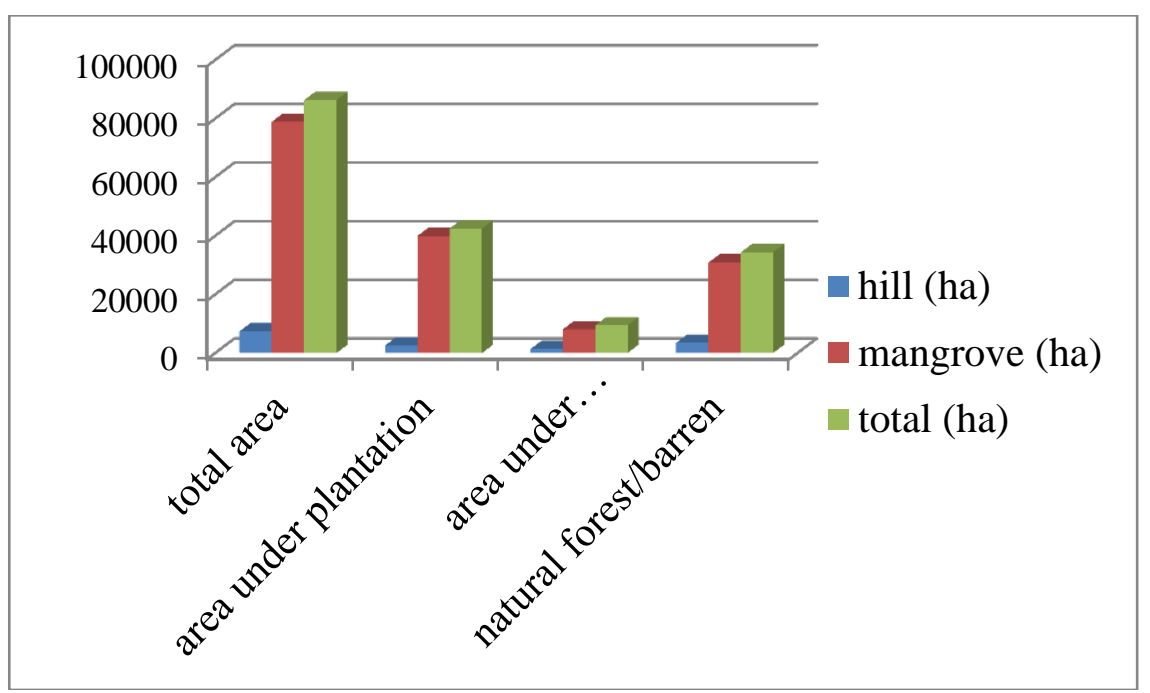

Figure 3: Area of Reserve Forest under Chittagong Coastal Forest Division

Effective role of coastal plantation along the coast during natural disaster

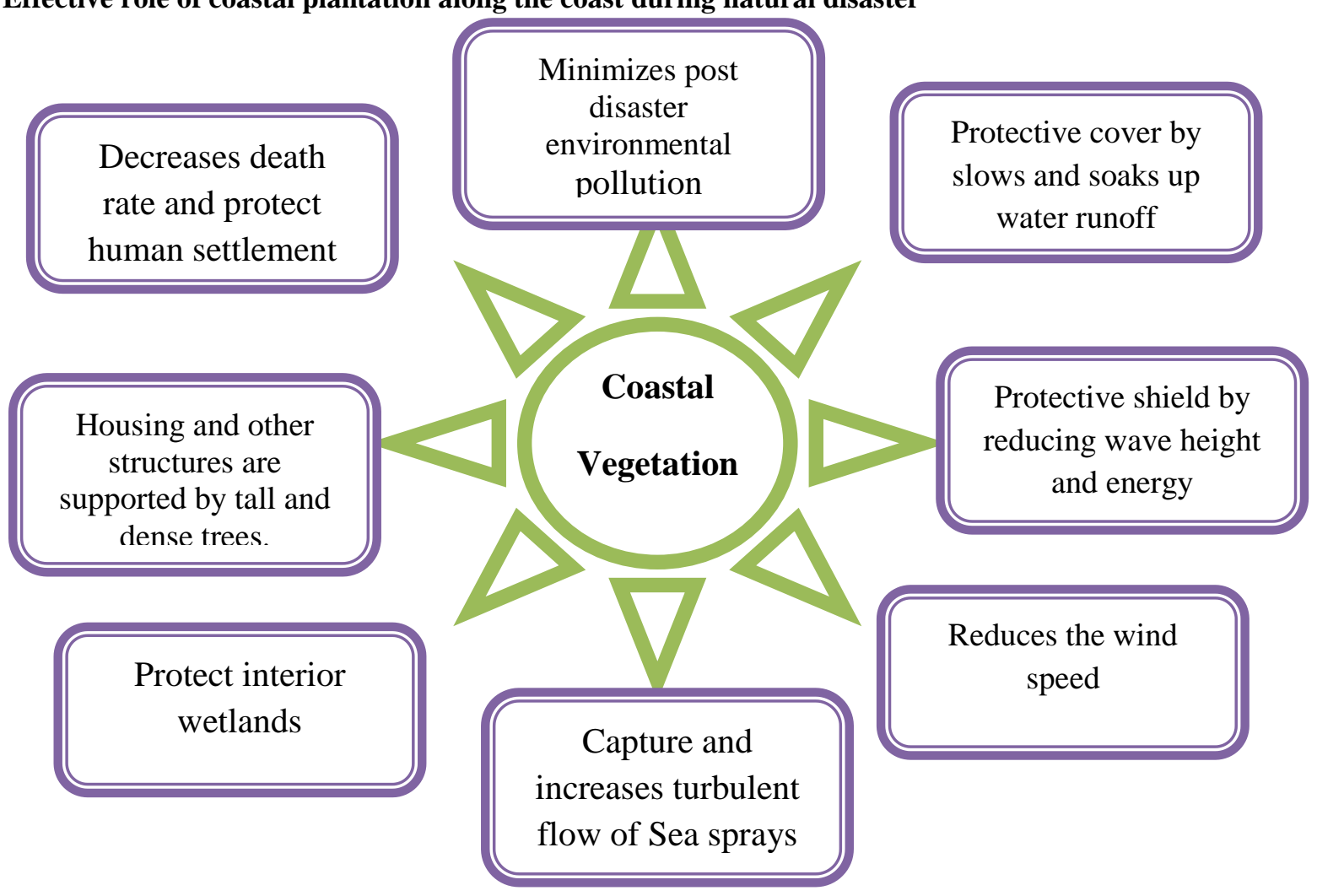




\section{Conclusion}

Coastal plantation program under different projects were raised in Chittagong Coastal Forest Division. Among different types of species mangrove species were dominant. Coastal plantation program has come into being primarily to reduce the effects of cyclones and tidal surges by creating a protective belt of coastal forests. Plantation along the shoreline undoubtedly influences the surrounding environment. The important roles played by coastal plantation are: protection of life and property during disasters, conservation and stabilization of newly accreted land, creation of employment opportunities, and development of suitable environment for the biodiversity. So the study highlighted the overall situation of coastal plantation in Chittagong Coastal Forest Division and their necessity to protect the natural environment from natural calamities.

\section{References}

[1]. Al-Hossaini, T.M., Habib, A. and Hossain, M.A. 2005. MULTI-HAZARD DISASTER REDUCTION IN THE COASTAL REGION OF BANGLADESH. International Symposium Disaster Reduction on coasts. Scientific-sustainable-Holistic-accessible, 14-16 November 2005 Monash University, Melbourne,Austrelia. P.2.

[2]. Aziz,A. 2010. Coastal and marine plant resources of Bangladesh: management and exploitation. Keynote paper, Annual Bot. Conf., Univ. Chittagong, Chittagong. P. 14

[3]. Bandyopadhyay,A.K. 1997.Coastal soils and Their Management. International Book Distributors. Rajpur road, Dehradun. P.179.

[4]. Bhuiyan, R.S., and Anam, M.K.2006. Physical Geography. Shahittokosh, 38, Bangla Bazar, Dhaka. P. 382.

[5]. Choudhuri, A.B. and Choudhury, A. 1994. Coastal of the Sunderbans Vol. 1. India. IUCN, Bangkok. P. 247.

[6]. Choudhury, S.Z. 1982. Coastal afforestation in Bangladesh, In: proc. Bangladesh National Conference on Forestry (Jun 21-26). Forest Department, Dhaka. P.170-190.

[7]. CZPo, 2005. Coastal Zone Policy, Ministry of Water Resources, Government of the People's Republic of Bangladesh, Dhaka. In: Sarwar, M.G.M. 2005. Impacts of Sea Level Rise on the Coastal Zone of Bangladesh. Thesis paper. Lund University, Sweden. P. 6.

[8]. Drigo, D., Latif, M.A., Chowdhury, J. A., and Shaheduzzaman, M. 1987. The Maturing Coastal Plantations of the Coastal Afforestation Project. UNDP project BGD/85/085, Dhaka. Field Document No.2. P. 3.

[9]. Hossain , M.K., Alam, M.K., and Miah, M.D. 2008. Forest restoration and rehabilitation in Bangladesh. In: Keep Asia Green, vol.III, South Asia, Don Koo Lee (ed.), IUFRO World Series, Volume 20-III, Vienna. P.21-66

[10]. Islam, M.M. 2007. Coastal forest rehabilitation and management in Bangladesh. P.1-5.

[11]. Karim, A. 1994. The physical environment P. 11-42. In: Hussain, Z. and Achanya, G. (eds.). Coastal plantation of the sunderbans, 2. Bangladesh, IUCN, Bangkok.

[12]. Lyche, M. 1991. Protection of sea dykes through planting of trees. Appraisal of the forestry component of WFP project Vietnam 9617 Rehabilitation and upgrading of sea dykes. Rome, World food programme.

[13]. Rachid, M. 1977. Instruction Manual for Planting on Coastal Area Departmental instruction manual. P.76.

[14]. Siddiqi, N.A. 2001. Mangrove Forestry in Bangladesh. Institute of forestry and Environmental Sciences, University of Chittagong, Chittagong. P.201 